\title{
WHAT THE EMERGING PROTESTANT THEOLOGY WAS ABOUT. THE REFORMATION CONCEPT OF THEOLOGICAL STUDIES AS ENUNCIATED BY PHILIP MELANCHTHON IN HIS PROLEGOMENA TO ALL LATIN AND GERMAN VERSIONS OF LOCI
}

\author{
MATTHEW OSEKA* \\ Concordia Theological Seminary, Hong Kong
}

\begin{abstract}
The present paper examines the rudimentary concept of the Protestant theology as an academic discipline which was enunciated by Melanchthon in his prolegomena to all Latin and German versions of Loci which were the instrument indispensable for educating a next generation of the Protestant divines and for disseminating the ideas of the Reformation worldwide.
\end{abstract}

KEY WORDS: Philipp Melanchthon, Loci communes, Loci theologici, Loci praecipui, Wittenberg Reformation, Systematic Theology, Jean Calvin

\section{Melanchthon as a 16th-Century Pan-Protestant Theologian}

Despite the fact, that the contemporary Protestant theology is beset with questions and doubts, it is advisable to examine the 16th-century roots of Protestant theological endeavours. For 16th-century theologians espousing the Reformation tenets, it was evident that the old, Catholic theological paradigm was challenged by Martin Luther (Melanchthon 1560b: A2r; Melanchthon 1546c; Melanchthon 1839: 155-170; Melanchthon 1855: 45-48), while the foundations for a new, emerging Protestant theology as an academic discipline were laid by Philip Melanchthon who was acclaimed as 'Praeceptor Germaniae' namely as the 'Teacher of the German-speaking world'. In fact, Melanchthon's influence extended to other European territories as well (Beyer 1997-2012; Dingel 2011; Frank 2001-2002; Maag 1999; Pauli 1996; Scheible 1997; Schofield 2006; Stolt 1998).

* MATTHEW OSEKA (ThD 2008, Christian Theological Academy in Warsaw, Poland) teaches historical theology at Concordia Theological Seminary in Hong Kong. Email: matthew.oseka@yahoo.com. 
By his textbook of the systematic theology (Loci) and by the theory underlying that manual, Melanchthon initiated a new way of theologising which was treasured not only by the proponents of the Wittenberg Reformation. John Calvin, for instance, effected the French translation of Melanchthon's Loci which was published twice in the 16th century (Melanchthon 1546a; Melanchthon 1551). The translator(s) thereof could not be identified (Melanchthon 1855: 667-670) but it is conceivable that Calvin himself translated Loci into French. Both editions of the French Loci were almost identically prefaced by Calvin (Melanchthon 1546a: 2r-4v; Melanchthon 1551: IIr-Vr). Additionally, the edition of 1551 contained a foreword (Melanchthon 1551: 5v) which was plausibly authored by its publisher Jean Crespin. The French translation of Melanchthon's Loci was based on the Latin edition of 1543. Moreover, in 1555 Calvin decided to provide a preface for the French translation of Melanchthon's commentary upon the Book of Daniel (Melanchthon 1555: 9-11). [Again, the translator is unknown.]

Calvin's admiration for Melanchthon's theological enterprise is wellknown and a close theological and personal bond between them has been thoroughly examined (Schaff 1958: 385-398; Zachman 2006: 29-53; Frank 2005; Pitkin 2004: 345-378). In Calvin's eyes, Melanchthon acted as a beacon to the 16th-century humanities and he was the most illustrious doctor of the renewed church founded on the Scripture alone (Calvin 1877: 386). In his writings, Calvin paid homage to Melanchthon as to a pillar of Reformation theology (Calvin 1867: 229-230) and did not hesitate to convey a sense of his profound Christian intimacy with Melanchthon publically (Calvin 1870: 461-463).

In his preface to the French translation of Melanchthon's Loci Calvin recommended and endorsed Loci as an impeccable and lucid exposition of the biblical way of salvation. At the same time, Calvin admitted a difference between his own views and Melanchthon's system as far as the concept of human free will and the concept of divine predestination were concerned. This difference Calvin regarded as extraneous to the academic and theological excellence of Loci. [The same reasoning is found in Calvin's letter to the members of the city council (seigneurs) of Geneva. In that official letter, Calvin tried to explain why his own views on human free will and divine predestination appeared to be at variance with those expressed in Melanchthon's Loci published and affirmed by Calvin himself (Calvin 1875: 371383).]

In his preface, Calvin did not espouse the idea of counting absolution among the sacraments which he attributed to Melanchthon. Actually, Melanchthon's concepts of human free will and of divine predestination as enunciated in his Loci of 1543 (Melanchthon 1544b: 22v-26v; 90r-92v) [the 
cited edition is a reprint of 1543 edition] and later in his Response to the Articles of the Bavarian Inquisition (Melanchthon 1824: 45-64) did not entirely coincide with Calvin's position. Nonetheless, with regard to absolution, in his Loci of 1543 (Melanchthon 1544b: 104r-122r) Melanchthon only pondered over a possible number of particular sacraments which would be contingent upon different definitions of the sacrament adopted for argument's sake. This approach was characteristic of his entire sacramentology (Herrlinger 1879: 119-123). To put it simply, whether absolution was classified as a sacrament or not, depended on how sacraments were defined.

The literature on the history of Melanchthon's Loci (Hardt 1717: 20-30; Rödiger 1829; Strobel 1776), on the development of Melanchthon's theology (Bizer 1964; Brüls 1975; Galle 1840; Geyer 1965; Greschat 1965; Heinrich 2003; Kuropka 2002; Matz 2001; Maurer 1964; Maxcey 1980; Plitt and Kolde 1890: 3-56; Neuser 1968; Schäfer 1961; Scheible 2010; Sell 1897; Schwarzenau: 1956) and on the doctrinal features thereof (Dingel 2012; Engelland 1930; Graybill 2010; Wengert 1997; Wengert 1998) is indeed vast, not to mention studies of Melanchthon's exegesis and of his reception of the church fathers, as well as analyses of his contribution to European philosophy and education. Therefore, the present paper aims to explore the rudimentary concept of Protestant theology as an academic discipline which was enunciated by Melanchthon in his prolegomena to all Latin and German versions of Loci.

\section{A Classification of Melanchthon's Prolegomena to Latin and German Loci}

The number of various editions of Latin and German Loci is enormous and it can hardly be estimated (Bindseil 1868; Claus 2014; Melanchthon 2010: 50-67; Strobel 1776; Strobel 1782) because, on the one hand, Melanchthon was on a regular basis rewriting his Loci, and on the other hand, Loci were published countless times. Since Georg Theodor Strobel, Melanchthonscholars have been dividing Loci into three versions (sing. aetas, plur. aetates) and 'Corpus Reformatorum' embraced that practice too.

Nonetheless, the above division seems to be inadequate as far the second and third versions of Loci are concerned granted that there are two types of Loci within the second version and two types within the third version. Although 'Corpus Reformatorum' contained both types of Loci classified as belonging to the second version (Melanchthon 1854b: 253-560), in the case of the third version 'Corpus Reformatorum' contained only the text of 1559, omitting the text of 1543 which was not identical with that of 1559 edition (Mayes 2011: xiii-xv). The latter is commonly recognised as the ultimate version of Loci, yet in 1560, shortly before his death, the final text of Loci was approved of by Melanchthon and printed as a part of Latin 'Corpus Philippicum’ (Melanchthon 1560b: 309-749). To identify what version 
of Loci is dealt with, it is necessary to consult the text, not necessarily the date of publication, given that earlier versions of Loci were occasionally released while later versions were already circulating.

Melanchthon's prolegomena (i. e. prefaces and dedicatory letters) scrutinised in the present essay are found in 'Corpus Reformatorum' except for the elucidation ('Argumentum') of Psalm 32 which was taken from Hessus' Psalter (Hessus 1544: 102-104) and which was included in many editions of Loci in Melanchthon's lifetime (Melanchthon 1546b: A8r). It is not clear whether the text of that 'Argumentum' was authored by Hessus himself or by Melanchthon who by writing the aforementioned elucidation could contribute to that new, annotated Latin Psalter. This Psalter was actually edited by Hessus and prefaced by Melanchthon (Hessus 1544: 18-20). The manner of placing the 'Argumentum' in Loci would point to Melanchthon as to its author.

In 1560 Johannes Nysaeus published the logical tables based on Loci which were prefaced by Melanchthon (Nysaeus 1560). Since Johannes Nysaeus was Melanchthon's student (Nysaeus 1560: A2r) and his book was published by Oporinus whose publishing house was renowned for printing numerous editions of Loci in Melanchthon's lifetime, the aforementioned preface should be reckoned as genuine (Strobel 1776: 251-256) and by virtue of its content it should be counted among Melanchthon's prefaces to Loci. In that preface, Melanchthon himself admitted that he was prefacing Loci transformed into a tabular format by Nysaeus (Nysaeus 1560: A5r). Moreover, the phrasing of Melanchthon's preface published in Nysaeus' Tabulae resembles that of Melanchthon's preface to the Latin version of ‘Corpus Philippicum' (Melanchthon 1560b: A2r-A4r) which was also written in early 1560, and Melanchthon's disquisition on the authority of the Scripture found in his preface to Tabulae partially overlaps with his statement ('consilium') from March 1560 (Melanchthon 1842: 1081-1083). [To be precise, the preface to the Latin version of 'Corpus' was written in February 1560, whereas the preface found in Nysaeus' logical tables in January 1560.]

In the present article, Melanchthon's prefaces to the Latin and German versions of 'Corpus Philippicum' are consulted too because they cast light upon his understanding of the emerging doctrinal texts which were to be held in high esteem (called later 'symbolic books') and because they capture his insights into the formation of collections of such texts (corpora doctrinae).

Melanchthon was intent on using the prolegomena to define the new, emerging theology as an academic discipline, situating it against the ancient and mediaeval theological paradigm. In the case of Melanchthon, most of his prefaces to his own writings or to the works authored by others were concerned with methodology and verged on the meta-theory of a specific 
academic discipline. For instance, in his preface to Physics (1549) Melanchthon explicated the phenomenon of natural sciences from the philosophical and theological perspective (Melanchthon 1567: A2r-A6v).

The first German version of Melanchthon's Loci was translated by Georg Spalatin (Melanchthon 1522) and published in 1522. That translation had subsequently been revised by Spalatin and printed many times by various publishers under various titles. From 1523 onwards Spalatin's preface (Melanchthon 1523a: A1v) had been added to that version of German Loci. In literary terms Spalatin's rendition slavishly imitated the Latin original and in the first edition of his translation Spalatin mishandled certain passages which were partially emended in the subsequent editions. [For example, '[...] siquidem hoc est Christum cognoscere, beneficia eius cognoscere [...]' was initially misinterpreted as '[...] das ist den Herrn Christum erkennen seine Gottheit erkennen [...]', while in the edition of 1523 translated correctly as '[...] das ist den Herrn Christum erkennen seine Wohltat erkennen [...]'. Melanchthon 1854b: 85; Melanchthon 1522: B1v; Melanchthon 1523a: 5v.]

The second version of Loci was translated (Melanchthon 1536) into German and prefaced (Melanchthon 1536: A2r-A4v) by Justus Jonas and released for the first time in 1536, while the German translation of the third version prepared by Jonas but refined by Melanchthon was published in 1542. The title page of that edition stipulated that in 1542 Melanchthon again proofread and refined the translation (Melanchthon 1544a). [the cited edition is a reprint of 1542 edition.] Since that edition stemmed from 1542, it is arguable whether that note might imply that Melanchthon proofread former German translations of his Loci. In the next editions, the date of Melanchthon's proofreading was adjusted accordingly.

The proposition that Melanchthon was involved in refining German translations of his masterpiece is plausible in view of his long-standing, close cooperation both with Spalatin and with Jonas (Baumgarten 1754: 408-411; Sotheby 1839). [The latter book (Sotheby 1839) documented Melanchthon's notes on German translations of Loci owned by him.] The examination of the Olomouc (German: Olmütz) manuscript of German Loci (Stupperich 1973: 351-370; Melanchthon 2010: 17-73) proved that Melanchthon himself prepared a draft of the German translation of the third version of his Loci which was later utilised by Jonas. The relationship between Melanchthon's rendition and the earlier German translation devised by Jonas but proofread and refined by Melanchthon still awaits further scrutiny especially in view of Melanchthon's own comments (Melanchthon 1840: 1137; Melanchthon 1841: 58; 607).

The note on the title page of 1542 edition ('in 1542 again proofread and refined by Melanchthon'), which represented the third version of Loci, 
might suggest that Jonas had access to the Latin original of the third version before its official publication in 1543. The final text of the third version of German Loci endorsed by Melanchthon was contained in the German ‘Corpus Philippicum' (Melanchthon 1560a: 371-783).

Speaking of numerous editions of German Loci belonging to every single version, it should be noted that while revising their translations, Spalatin and Jonas were not only refining their German but also took the opportunity to implement minor changes which were meanwhile made by Melanchthon in the new Latin editions. In the present paper, German translations of Loci are construed as auxiliary to and illuminative of the Latin original and therefore are referred to occasionally.

\section{Christian and Jewish Endeavours to Systematise Religious Instruction in Antiquity and in the Middle Ages}

A systematic (topical) value of Melanchthon's Loci can be discerned by situating that manual against the ancient and mediaeval endeavours to systematise religious instruction within the Christian and Jewish traditions. Although the religious literature produced by the ancient church was vast and diverse, initially it was not abundant in the presentations of the Christian doctrine which could be construed as systematic from the contemporary point of view. Naturally, the contemporary concept of systematicity was largely formed in the late Antiquity or in the early Middle Ages, depending on a specific chronology adopted with reference to a particular region. Needless to say that the inception of the mediaeval period was less conspicuous in the Byzantine Empire than in the West.

The ancient church fathers were preoccupied with explaining and fortifying what was perceived by them as an orthodox Christian doctrine. This happened predominately through edifying or polemical expositions of basic Christian concepts (Origenes 1857: 115-414; Eusebius Caesariensis 1857a: 13-794; Lactantius 1844: 111-822; Ambrosius Mediolanensis 1880: 527-698; Augustinus Hipponensis 1843: 15-122; Augustinus Hipponensis 1845b: 231-290) or of specific ideas [a vast literature arising from the trinitarian and christological controversies belongs to that category], through commentaries upon the Apostles' Creed in the Western church (Rufinus 1878: 335386) or upon the Niceno-Constantinopolitan Creed in the Eastern church (Theodotus Ancyranus 1864: 1313-1348), through sermons and through catechetical (Cyrillus Hierosolymitanus 1857a: 331-1060; Cyrillus Hierosolymitanus 1857b: 1059-1128) or evangelistic (Eusebius Caesariensis 1857b: 21-1408) lectures and tracts.

In the first half of the 7th century, Maximus the Confessor (Maximus Abbas 1865: 1177-1392), the Greek church father, composed a theological compendium called 'Chief Topics'. As a matter of fact, a literal Latin transla- 
tion of that Greek title would be 'Loci praecipui'. The latter phrase was used by Melanchthon as a title for the second and third versions of his Loci. [Calvin named his masterpiece after Lactantius' work (Lactantius 1844).] Notwithstanding a mediocre deployment of theological content, Maximus' work was a harbinger of the systematic era within Byzantine theology. This era was exemplified by the monumental exposition of the Christian doctrine prepared by John of Damascus (Joannes Damascenus 1864: 789-1228) in the first half of the 8th century.

In the Western church presentations of the Christian essentials by Ambrose (Ambrosius Mediolanensis 1880) and by Augustine of Hippo (Augustinus Hipponensis 1845b) were conspicuous for their systematic treatment of doctrinal content. The tradition of such comprehensive expositions of Christian belief was continued by the Latin church fathers in the early Middle Ages (Vincentius Lirinensis 1865: 637-686; Fulgentius 1847: 671706. The latter was also attributed to Augustine. [Augustinus Hipponensis 1845a: 753-780) until the emergence of new theological genres called 'Sentences' and 'Summas'.]

In the first half of the 12th century Hugh of Saint Victor composed his Summa sententiarum (Hugo de Sancto Victore 1880: 41-174). From then on, mediaeval theologians were keen either on devising their own 'Sentences' or on writing commentaries upon Peter Lombard's Sentences (Petrus Lombardus 1855: 521-962) which enjoyed considerable popularity even in the early 16th century. Subsequently, in the 13th century Thomas Aquinas began to popularise his concept of theological summa organised according the dialectical method (question-thesis cum arguments-antithesis cum arguments-adjudication).

The preponderance of 'Sentences' and 'Summas' did not eliminate other forms of systematic presentation of Christian doctrine. For instance, Peter Abelard's Sic et non (Petrus Abaelardus 1855a: 1339-1610) was a highly philosophical and theological disquisition, yet his Theologia Christiana (Petrus Abaelardus 1855b: 1123-1330) was a communicative compendium resembling those of the ancient church fathers.

Although every 'Summa' or 'Sentences' should be studied in its own right, generally speaking, those forms of theological discourse put the emphasis on a philosophical argumentation to the detriment of the exegesis of the sacred writings. Moreover, neither ancient nor mediaeval Christian theology reflected upon the theological significance of systematising the Christian essentials and none of pre-Reformation theologians anticipated that the way of selecting and arranging the doctrinal content might be concomitant with theological tenets underlying any attempt at systematisation.

The Jewish tradition was focused on experiencing the Lord's Covenant with Israel which was recorded in the multi-layered religious literature such 
as Midrashim or Talmudim (Weber 1880) that had been solidifying at least since the Siege of Jerusalem in $70 \mathrm{AD}$. On account of the orthopraxy characteristic of Judaism, the Jewish religious tradition for a long time had not felt the need to delineate and to systematise the essentials thereof except for liturgical expression. [The comparison of the Rabbinic siddurim to the Karaitic ones proves that the liturgical texts, which from a contemporary perspective could be viewed as doctrinally significant, were common to both traditions. In view of the moment of the separation of the Karaite movement from the Rabbinic Judaism it is arguable that some texts contained in the siddurim were circulating prior to the aforementioned division.] Plausibly, the systematic expositions of the Jewish way of living (Saadia Gaon 1845; Judah Halevi 1905; Maimonides 1923-1924; Abraham ibn Daud 1852; Albo 1844) were precipitated by the encounter with the systematic methods of arguing religious ideas which were employed in Islam and in Christianity. Nonetheless, the mediaeval discussion about the status and function of the Thirteen Principles propounded by Maimonides demonstrates that the systematisation of religious propositions was not indispensable to the Jewish tradition which was perpetuated, preserved and transmitted by non-systematic forms of a religious literature, by practising the Law and by worshipping the Lord.

\section{God's Word as the Sole Source and Means of the Saving Knowledge of God}

In his prolegomena, Melanchthon highlighted the supreme and unique authority of the Scripture within the church and defined the relationship between the Bible and other texts relevant in doctrinal terms. Furthermore, he propounded the method of biblical interpretation which he considered credible and implied by the Scripture itself.

In Melanchthon's view (Melanchthon 1854b: 81-84; 253-255; 341-349; 601-607; Melanchthon 1855: 45-52; Nysaeus 1560: A4v-A5r; Melanchthon 1842: 1083), the Scripture, which he identified as a written form of God's Word [thus, Melanchthon recognised the Scripture as inspired by the Holy

Spirit] was the sole source and means of the saving knowledge of the Divinity for human beings. Consequently, every single statement concerning a Christian belief or a Christian life had to be grounded in the Scripture in which, according to Melanchthon, the saving self-revelation of God towards humankind was fully and sufficiently enshrined.

Melanchthon maintained that by adhering to the Scripture as to the sole source of the saving knowledge of God, the church was retaining its biblical (whence orthodox) identity as envisaged in Ephesians 2:19-20. For that reason, Melanchthon commonly referred to the Scripture as to the "prophetic and apostolic writings or books' in order to emphasise that the church irre- 
spective of its historical or regional form must be founded upon the Bible from which all Christian doctrine should originate and by means of which the complete self-revelation of the saving face of God was laid bare to humankind.

From Melanchthon's standpoint (Melanchthon 1854b: 601-607), theologians, who either taught contrary to the Scripture or conveyed a message not attested in the Bible, were to be considered heterodox. Accordingly, not only a proposition adverse to the Scripture but also a proposition not substantiated in the Scripture should be considered heterodox. Therefore, Melanchthon was passing strictures on divines who dared to 'fabricate the doctrine(s)', namely, to make assertions which could not be proved from the Bible.

In his opinion, the Scripture itself laid claim to the church and imposed its uncompromising authority on the church. Therefore, by evoking terms such as 'ecclesiastical doctrine' or 'doctrine of the church', Melanchthon recalled that the biblical doctrine in its pure form was the only one which was supposed to be professed by the church regardless of its historical or geographical setting.

Realising that some knowledge of God, to be precise, a limited [on account of the original sin, as Melanchthon taught] knowledge of the divine Law, could be known from the universe and from human innate moral awareness (the conscience), and therefore was available apart from the Scripture, Melanchthon (Melanchthon 1854b: 253-255; 347-349) clarified that the Bible was the sole repository of all saving knowledge of God, to wit, of the entire message concerning the salvation of sinners (the Gospel).

Given the absolute primacy of the Scripture over the church, Melanchthon (Melanchthon 1854b: 81-84; 253-255; 603-607; Melanchthon 1855: 45-48) avowed that no other text could be equated with the Bible or might approximate to the Bible. Therefore, Melanchthon stated that his Loci were meant not to entice the audience away from the study of the Bible but rather, by acting as a guide to the essentials of the biblical teaching, to entice the readers to plunge into the Scripture and to guard the absolute authority thereof. For that reason, some editions of Melanchthon's German Loci were titled 'Anweisung in die wahrhaftige heilige Schrift Gottes', namely, 'An introduction to the true and holy Scripture of God' (e. g. Melanchthon 1523a). The position of Loci as utterly subservient to the Scripture was also underscored both by Spalatin (Melanchthon 1523a: A1v) and by Jonas (Melanchthon 1536: A2r-A4v) in their forewords to the German renditions. While working as a systematic theologian and as an exegete, Melanchthon was concerned that his expositions of the Christian doctrine or his biblical commentaries might be perceived by some readers as competing against the Scripture. 
In the edifice of Melanchthon's theology non-biblical texts of paramount importance can be divided into the ecumenical creeds and the documents produced by the 16th-century Wittenberg Reformation. The ecumenical creeds, i. e. the Apostles' Creed, the Niceno-Constantinopolitan Creed, and the Athanasian Creed, were regarded by Melanchthon as an accurate summary of the biblical doctrine and as a trustworthy recapitulation of the distinctive points of the biblical message functioning as a token ('symbolum') of the doctrinal orthodoxy (Melanchthon 1855: 51-62; Nysaeus 1560: A4vA5r; Melanchthon 1854b: 333-340). Melanchthon affirmed that the ecumenical creeds were handed down as a comprehensive and comprehensible epitome of biblical teaching which ought to be professed by the church without reservation.

Therefore, Melanchthon (Melanchthon 1855: 45-48; 51-62; Nysaeus 1560: A4v-A5r; Melanchthon 1854b: 341-348; 601-607) did not hesitate to admit that the Scripture cum the ecumenical creeds, which were thought of as duly encapsulating its message, was the perennial fountainhead of the Christian teaching on the stipulation that the Scripture was the only source, while the symbols were merely affirming, reflecting, and epitomising the biblical message. The Scripture as the sole source of doctrine was evoked in an exhaustive subtitle of 'Corpus Philippicum' which was designated as 'the summary of the orthodox and universal articles of faith embracing the pure and true doctrine of the Gospel of Jesus Christ according to the divine writings of the prophets and apostles' ('summa orthodoxi et catholici dogmatis complectens doctrinam puram et veram Evangelii Jesu Christi secundum divina prophetarum et apostolorum scripta'). Thus, the ecumenical creeds, which were contained in that collection of Melanchthon's writings ('Corpus Philippicum'), were a part of the summary and exposition of the doctrine which was construed by him as derived from the Scripture alone.

Treating of the relationship between the Bible and the church fathers, Melanchthon (Melanchthon 1854b: 333-340) mentioned that in the Scripture as in the sole fountainhead of the divine wisdom the doctrine was revealed and laid down. This doctrine was subsequently epitomised in the ecumenical creeds, while the church fathers proved to interpret that doctrine more or less adequately. The ecumenical creeds were also held in high esteem by some of Melanchthon's associates who would say that the Christian doctrine was embodied in the Scripture and in the ecumenical creeds, yet only the 'prophetic and apostolic writings' (i. e. the Bible) could enjoy the status of God's voice ('vox Dei') and could be received as such (e. g. Crell 1560: G1v-G2r; Melanchthon 1842: 1081-1083; Melanchthon 1837: 717). Similarly, Melanchthon opined that the divine doctrine was transmitted and enshrined in the Scripture, whereas the ecumenical creeds duly recapitulated it (Melanchthon 1842: 782). 
Melanchthon did not advocate the apostolic authorship of the Apostles' Creed but settled for the statement that the aforementioned creed was formulated by the church in the apostolic age (Melanchthon 1855: 51-62). Nonetheless, Melanchthon's approach to those three creeds, which he termed ecumenical, ignored their historical context because neither the Apostles' Creed nor the Athanasian Creed was acknowledged as ecumenical by the Eastern church which unwaveringly cleaved to the NicenoConstantinopolitan Creed in its original Greek wording ('scilicet' without 'filioque') as to the only ecumenical symbol of faith endorsed by the ecumenical councils. Thus, to buttress the unique status of the NicenoConstantinopolitan Creed, Eastern theology distinguished between that creed and the doctrinal definitions ('formulae') made by the ecumenical councils. In short, Melanchthon's concept of the ecumenical creeds was a sheer product of Western mediaeval theology which eo ipso hindered any dialogue with the Eastern church in the 16th century (Andreä 1584).

Melanchthon did not accord to the documents of the 16th-century Reformation the same status which he assigned to the ecumenical creeds but rather construed the confessions of faith made by the proponents of the Reformation as a remedial work which in his opinion was a preliminary attempt at renewing the visible church by bringing it into compliance with the pure Christian doctrine embodied in the Scripture alone and genuinely mirrored in the ecumenical creeds.

Among the doctrinal texts produced by the 16th-century Wittenberg Reformation Melanchthon especially appreciated his own Augsburg Confession and its derivatives namely the Apology of the Augsburg Confession and the Saxon Confession (Melanchthon 1560b: A2r-A4r; A5r-A6v; Melanchthon 1560a: A2r-A3r; A4r-A5v; Melanchthon 1854b: 333-340; Melanchthon 1855: 45-62). Although the Augsburg Confession, which was a public declaration of faith made by German princes and city councils, was authored by Melanchthon and consented to by Luther, Melanchthon did not inflate the status of that confession against the authority of the Scripture or against the position of the ecumenical creeds. Rather, Melanchthon asserted that the stark deviation of the Catholic mediaeval church from the biblical standards as understood by the Reformers necessitated the work of renewal to which Confessio Augustana contributed significantly as the instrument for rediscovering, formulating, disseminating and enacting the biblical teaching.

Melanchthon viewed his other writings purely in terms of their educational potential to transform the life and mind-set of next generations in compliance with the biblical doctrine and in accordance with the Reformation concept of the vocation which affirmed and promoted Christians' involvement in all social, educational, economical and political affairs. Thus, the Reformation assigned a supermundane value to the mundane activity 
by which Christians were said to serve the Creator of the universe who was believed to endow every single human being with his or her station in life.

For Melanchthon, a theological practice involved a continual and collective dialogue because in his view doctrinal issues should be brought up for constant discussion among Christian literati within the parameters defined by the authority of the Scripture in order to avoid an unnecessary discord and in order to reach a consensus (Melanchthon 1560b: A2r-A4r; Melanchthon 1854b: 333-348; 601-604). It should be noted that, according to Melanchthon, not only professional theologians but also Christian rulers and illustrious representatives of the entire society were authorised to participate in such a theological discourse because in his opinion the Christian community as such was responsible for the purity of the religious life.

Melanchthon appealed to the ecumenical councils which delineated the patristic orthodoxy, presuming that the collective and dialogical manner of solving theological controversies and of formulating doctrinal statements could provide a broad basis for Reformation theology. Affirming the authority of Scripture and the credibility of the ecumenical creeds, Melanchthon was prone to construe other theological propositions as provisional so that they might continue to be revisited and examined in the light of the Bible. As for his own doctrinal statements, Melanchthon did not consider them infallible but rather urged other theologians to evaluate his writings freely and openly from the perspective of biblical authority (Melanchthon 1854b: 601-604; Melanchthon 1855: 45-48). The only credit, which Melanchthon was willing to take, was that for expounding the Scripture, particularly, the biblical message concerning the salvation of sinners (the Gospel), in a systematic way. This Melanchthon saw as his own contribution to the Reformation initiated by Luther (Melanchthon 1854b: 341-348).

Since in Melanchthon's opinion the Scripture lent credence to the ecumenical creeds and was the sole criterion for the verification of theological propositions, he was attentive to the method of the biblical interpretation. For Melanchthon (Nysaeus 1560: A4v-A5r; Melanchthon 1842: 1083), any certainty in the sphere of the doctrine could be derived only from the Scripture interpreted according to a simple, unequivocal and unchangeable meaning inherent in the linguistic and historical setting of the biblical text. Consequently, to treat the Bible as perspicuous in doctrinal terms, it was necessary to rely on its most natural sense which would have to be rooted in the literary and historical context. Therefore, Melanchthon was opposed to far-fetched interpretations of the Bible especially to the allegorical method (Melanchthon 1854b: 81-84). In his opinion, the allegorical interpretation was inadmissible because it consisted not in discovering a reliable meaning enveloped in the text but rather in fabricating a meaning at a reader's dis- 
cretion. Such an approach Melanchthon regarded as subjective and as potentially deceptive.

Animadverting upon the allegory as an illicit method of the biblical interpretation, Melanchthon (Nysaeus 1560: A4v) cited Epiphanius of Salamis (Epiphanius 1863: 1047-1048) who in his view disapproved of an excessive use of the allegory attributed to Origen. Actually, in the passage quoted by Melanchthon Epiphanius did not challenge Origen personally but rather admitted that the allegorical method, which was widely accepted and cherished by the Greek church fathers, should be used within the parameters defined by the doctrinal authorities of the imperial church. In the next sentence Epiphanius stated that regardless of an adopted method of the biblical interpretation the Scripture alone could not be acknowledged as sufficient in doctrinal terms because in his opinion the Bible must be interpreted in light of the ecclesiastical tradition and must be supplemented by that tradition.

In this respect, Melanchthon's reference to Epiphanius was taken out of context and was harnessed to Melanchthon's Reformation agenda. Clearly, Melanchthon was intent on emphasising that even the ancient church fathers were not pleased with an excessive use of the allegorical method and therefore he resorted to Epiphanius' remark, which was cited (Nysaeus 1560: A4v) in Greek and paraphrased (Melanchthon 1842: 1083) in Latin. This passage was subsequently quoted by Bartholomäus Keckermann (Keckermann 1606: 68-69), the 16th-century Protestant luminary from Danzig, who drew on Melanchthon's preface and who provided another Latin translation of that piece.

Melanchthon's Latin paraphrasis of Epiphanius' comment coincided with Melanchthon's assertion that the ancient and mediaeval theologians ventured to apply the allegorical method of the biblical interpretation to the doctrinal issues in order to vindicate theses which otherwise could never be argued from the Scripture. In fact, Melanchthon (Nysaeus 1560: A4v-A5r; Melanchthon 1842: 1083) charged Catholic theologians with the statement that the Scripture was vague about the Law and the Gospel, and he countered it by declaring that if the Scripture was interpreted properly, it was indeed explicit about the distinction between the Law and the Gospel which in his opinion underpinned all articles of faith.

Melanchthon's opposition to the allegorical method of interpretation primarily arose from his commitment to entrench the perspicuity and sufficiency of the Scripture in the realm of the Christian doctrine. In the next section, we will discuss the hermeneutic relevance of the distinction between the Law and the Gospel which, according to Melanchthon, was not simply one of the articles of faith but rather the category ensuring a proper perception and application of all articles of faith. 
Pondering Epiphanius' remark, Melanchthon observed that through experience mediated by senses human beings were able to learn what words signified (Nysaeus 1560: A4v-A5r; Melanchthon 1842: 1083). Thus, the very experience disclosed to human beings what was meant by words such as life, death, fear, sorrow or delight. For Melanchthon, although the experience empowered people to capture what the words denoted, the text was invested with a definite meaning not by its original or contemporary readers but rather by its historical and literary setting. Therefore, Melanchthon argued that any experience on a reader's side could only illustrate the biblical text without altering or influencing its genuine meaning which, as inherent in the text, was not to be created but rather to be discovered by the audience.

For Melanchthon, the authentic signification of the text was not crafted by the process of analysing it or drawing inferences from it (Nysaeus 1560: A4v-A5r; Melanchthon 1842: 1083). In his view, human senses were occupied with discovering the meaning of words, while human reason was tasked with drawing inferences from them and with enunciating and organising concepts on that basis. Therefore, Melanchthon contended that the process of analysing and systematising theological data did not affect their veracity but rather put various elements of the biblical doctrine in order just as bricks must be put together properly and according to a blueprint to construct a durable building (Melanchthon 1855: 51-62).

Nowhere in his works Melanchthon did espouse the idea that the Scripture should be interpreted according to non-biblical texts (such as church confessions, for example) because this would imply that the outcome of the biblical interpretation was posited prior to the linguistic and historical study of the text. Rather, Melanchthon maintained that the linguistic and historical analysis of the Scripture would eventuate and culminate in the teaching embodied in the ecumenical creeds. Actually, he could not imagine that results of the proper exegesis of the biblical text might be at variance with the 'ecclesiastical consensus' which he identified with the ecumenical creeds.

Melanchthon's handling of the ecumenical creeds was ahistorical not only because he treated all three creeds as ecumenical but also because he detached them from the patristic legacy. Since Melanchthon found in writings of the church fathers many propositions, which were in his opinion orthodox, and some, which were heterodox, he had to separate the ecumenical creeds, which he called the 'pure testimonies of the early church', from the entire patristic legacy which in his view should be examined critically and utilised only as far as it conformed to the biblical teaching as understood by the Reformers. Historically speaking, neither the Greek church fathers nor the Eastern church upheld such a position because they perceived the $\mathrm{Ni}$ ceno-Constantinopolitan Creed as an eminent part of the indivisible patris- 
tic legacy embracing writings of the Greek church fathers and the Byzantine liturgy.

\section{An Existential Orientation of Melanchthon's Theological Enquiry}

Melanchthon defined the function of theology as conveying the divine voice perpetuated in the Scripture by communicating the biblical message in an orderly and efficient way. To carry out that task, Melanchthon employed the category of loci qualified as communes, praecipui or topici which played a prominent role in the ancient (Aphthonius 1839: 27-34; Cicero 1820a: 59122; 191-289; Cicero 1820b: 12-14; 71-97; Cicero 1820c: 31-62; Hermogenes 1812: 28-31; Priscianus 1545: 871-873; Quintilianus 1725: 93-97; 285-307; 660-662; Aelius Theon 1834: 95-100), mediaeval (Boethius 1549a: 223-260; Boethius 1549b: 261-272) and Renaissance (Agricola 1550; Agricola 1554: 1r-143r; Erasmus Rotterdamus 1519: 177-179; Erasmus Rotterdamus 1540: 76-77; 86-91) dialectics that combined the contemporary disciplines of logic and rhetoric (Breen 1947: 197-209; Mack 1993: 320-333; Kolb 1997: 317-337; Kolb 2003: 509-514; Leiner 1997: 468-487; Wiedenhofer 1976). In his non-theological writings, Melanchthon developed the theory of loci as focal points (capita, elementa) which could be used as a means of organising the material in the humanities (Melanchthon 1525: [s. p.]; Melanchthon 1545: 168-199; Melanchthon 1584: 224-351; Melanchthon 1592: 65-70; Melanchthon 1854a: 748-764; Melanchthon 1523b: 11r-12r; Melanchthon 1850: 807-832). In fact, Melanchthon advanced the rhetorical concept of loci which were traditionally defined as reservoirs of arguments, and he viewed loci as the universal method of arranging the material in the humanities.

In Melanchthon's system, loci theologici (theological topics) served as focal points for theological discussion and instruction, and they were construed by Melanchthon as implied by the Scripture itself. Thus, by adhering to theological topics designated by the Bible, a student of the Scripture could be certain that he or she would be focused on what the Bible itself was focused.

According to Melanchthon, every theological topic should be studied from the perspective of Christ's work of salvation (Melanchthon 1854b: 8385). Consequently, the most incomprehensible features peculiar to the Christian concept of the Godhead such as the doctrine of the Trinity were to be adored by Christians instead of being inspected in philosophical terms. [Melanchthon's attitude towards the patristic concept of the Trinity was not ambivalent but clearly affirmative because he objected not to the doctrinal content thereof but rather to the philosophical, complex disquisition on the Godhead as embarked on by the Western mediaeval theologians (Fraenkel 1961; Hall 2014; Meijering 1983).] For Melanchthon, the substan- 
tial knowledge indispensable to the Christian identity presupposed that the individual human being considered himself or herself a sinner (the Law) and accepted the free gift of salvation earned by Christ for sinners the Gospel). Thus, all elements of the doctrine were to be explored from the viewpoint of Christ's work of salvation as far as they were revealed and embodied in the Scripture.

In his prolegomena, Melanchthon criticised the main theological compendia brought forth by the church fathers such as Origen (Origenes 1857), Rufinus of Aquileia (Rufinus 1878) [in Melanchthon's days that work was attributed to Cyprian of Carthage], Fulgentius (Fulgentius 1847) [in Melanchthon's days that work was assigned to Augustine. Augustinus Hipponensis 1845a] or John of Damascus (Joannes Damascenus 1864) and by the mediaeval theologians such as Peter Lombard (Petrus Lombardus 1855) or Thomas Aquinas [in the early 16th century an impact of Thomas' Summa on the Western theology was feeble as compared to that of Lombard's Sentences which still held sway in Melanchthon's time]. Melanchthon did not denounce them for departing completely from the biblical truth, because he realised that to a considerable degree those works contained what he recognised as the biblical teaching, but rather accused them of losing sight of the concept of salvation as central to Christian theology. According to Melanchthon, the vast majority of the ancient and mediaeval theologians became absorbed in philosophy, either by asking questions which could not be answered on the ground of the Bible or by adducing scriptural passages as proof in philosophical discussions.

Examining the focal points, which in his opinion were supplied by the Scripture, Melanchthon paid attention to the Epistle to the Romans and to the Book of Genesis. Actually, Melanchthon himself admitted (Melanchthon 1854b: 81-84) that the first version of Loci (1521) originated from his early notes on the Epistle to the Romans (Melanchthon 1854b: 11-60) in which Loci of 1521 were undoubtedly outlined and in which the foundations for Protestant theology as an academic discipline were laid. [Those early notes should not be confused with Melanchthon's mature commentaries on the Epistle to the Romans (Melanchthon 1848: 495-1052).]

It is legitimate to say that initially Loci were devised by Melanchthon as an explication of theological topics which in his opinion were accentuated in the Epistle to the Romans. This epistle Melanchthon viewed as the ideal summary of the Christian doctrine though neither the epistle itself nor the ancient church accorded such a status to the Book of Romans (Melanchthon 1854b: 83-85; 253-255; 333-348; 603-607; Melanchthon 1855: 51-62; Melanchthon 1835: 456-461; Schirmer 1967; Wengert 2009: 129-164). In fact, an undisguised elevation of Corpus Paulinum to the status of the hermeneutic hub of the Christian Scriptures was distinctive of the Reformation 
divines but unknown to the ancient church except to Augustine and to some of his proponents. The Eastern church construed the Pauline Epistles and other books belonging to the Christian Scriptures as complementary voices, bringing the entire collection of the sacred writings unique to Christianity into balance, and if any prominence was given by the Greek church fathers, it was given to the synoptic Gospels and the Gospel of John.

Melanchthon stated that a series of narratives found in the Book of Genesis (1-3) unveiled the essentials of the Christian doctrine by treating of the creation, human fall into sin and the promise of salvation as articulated in Genesis 3:15 (Melanchthon 1854b: 253-255; 347-349; 603-607; Melanchthon 1855: 51-62). For him, all articles of faith could be perceived and applied properly only if the distinction between the Law and the Gospel was observed. Consequently, the Law was defined as God's will concerning human life by virtue of which every human being was assessed by God and either blessed in reward for fulfilling the divine precepts perfectly or punished for any breach of the divine commandments. On account of Adam's and Eve's fall into sin Melanchthon argued that every human being was conceived and born as a sinner deserving eternal damnation.

The Gospel, on the other hand, was defined as God's message of the remission of sins for Christ's sake which according to Melanchthon was proclaimed for the first time immediately after Adam's and Eve's fall and recorded in Genesis 3:15. On that occasion, it should be noted that the Jewish exegetical tradition did not expound Genesis 3:15 as prophetic of the messianic seed, while the Christian Scriptures never interpreted that passage with reference to Christ. Nonetheless, the christological reading of Genesis 3:15 was distinctive of the Wittenberg Reformation, yet doubted by Calvin (Calvin 1882: 69-72).

Melanchthon taught that the clarity of the presentation both of the Law and of the Gospel was progressing throughout the Scripture. Thus, the Law, which was engrafted in human heart at the moment of the creation, was put into writing as attested in the Book of Exodus (the Sinaitic legislation), while the initial promise of the messianic seed in Genesis 3:15, as interpreted by Melanchthon, was fulfilled in Jesus to whom the Christian Scripture were said to bear testimony.

For Melanchthon, every proposition (Lehre) or narrative (Geschichte) found in the Scripture was indicative either of God's will embracing human life and its consequences (the Law) or of God's favour to sinners based on Christ's atonement (Melanchthon 1855: 51-62). Disregarding a common patristic presupposition, that the Hebrew Bible was equal to the Old Covenant (i. e. the Law), while the Christian Scriptures were identical with the New Covenant (i. e. the Gospel), Melanchthon announced that both the communication of God's demands (the Law) and the communication of 
God's mercy (the Gospel) were distributed among all books of the Scripture. Moreover, he tried to interpret narratives in the Tanakh, even those purely historical, either as an account of God's disapproval of Israel's trespasses (the Law) or as an account of God's approval of his Chosen People based on the divine covenant of grace (the Gospel). [As a matter of fact, the labels 'Old Testament' and 'New Testament' were not implied by those two collections of the sacred texts but rather invented by the early Christian church. Those pernicious appellations not only contravened the views on the Hebrew Bible expressed in Corpus Paulinum and in the Epistle to the Hebrews but also must be considered derogatory from a Jewish perspective.]

As a renowned humanist Melanchthon insisted that the relationship between the arts and theology, which he counted among the arts as well, should be defined clearly in order to be mutually beneficial (Melanchthon 1835: 460-461; Melanchthon 1855: 51-62; Melanchthon 1854b: 83-85; 253255; 333-349). For Melanchthon, every academic discipline must invent its method of arranging its material properly in view of the cause-effect relationship because otherwise no learning or teaching would be possible within the compass of that discipline. In his opinion, God created human beings to act and to proceed in an orderly and efficient way (Melanchthon 1854b: 603-607). Granted that theology was defined as a study of the sacred texts bearing testimony to the religious phenomena, Melanchthon claimed that such a study must involve the use of human reason because every text would await interpretation.

Melanchthon (Melanchthon 1854b: 83-85; 253-255; 347-349) argued that the method of loci, which was widely used in the humanities and which was advanced by him, could easily be applied to Christian theology. In fact, he supposed that the ecumenical creeds could be viewed as a product of an implicit use of that method because in those documents the rudiments of the Christians faith were gleaned from the Scripture and summarised according to the sequence of God's operation in the universe (creationredemption-sanctification).

For Melanchthon (Melanchthon 1854b: 333-340; 347-349; Melanchthon 1855: 57-58; Melanchthon 1560b: A2r-A4r), the arts and theology could enrich one another because theology might benefit from the expertise of the arts in the method of organising the material and in the field of the interpretation of sacred texts. Moreover, the arts could facilitate the pursuit of the civil uprightness and help cultivate the civil morality. Thus, by fostering loci philosophici such as justice, temperance or beneficence, philosophy could to a certain degree explore things appertaining to the divine Law. On the other hand, theology was able to adjudicate spiritual matters which could be reached neither empirically nor logically. 
Melanchthon was aware that the arts, especially philosophy, might influence theology in terms of its focus and content. Therefore, he acknowledged the message about the forgiveness of sins for Christ's sake as the cornerstone of theology which in his opinion should revolve around the assertion that by his life Christ fulfilled the Law in lieu of humankind (the active obedience), whereas by his death Christ experienced the penalty for humankind's transgressions (the passive obedience). As a consequence of that vicarious substitution, sinners were said to be declared not guilty in God's sight.

For Melanchthon (Melanchthon 1854b: 603-607), the arts and theology differed as far as their sources were concerned. Accordingly, all the arts except for theology verified their propositions either logically or empirically. These means of verification Melanchthon called the demonstration. Thus, the empirical verification consisted in the experience, whereas the logical verification was based on the logical principles which Philip considered innate. In theology, as Melanchthon claimed, the verification consisted in establishing whether a given statement could be substantiated by the Scripture interpreted according to its most natural (whence historical and literary) sense or not. Since the Scripture was designated by Melanchthon as the sole testimony to the saving self-revelation of God, a given statement was true if it could be argued from the Bible.

In Melanchthon's opinion, human heart could be convinced, that God's message was true, only by the Holy Spirit operating by means of that message, while the acceptance of the divine communication touching human sin and divine grace was said to cause a believer to recognise the Scripture as God's revelation ('testimonium internum Spiritus sancti'). Melanchthon contended that the Gospel disclosed God's favour to the world which human beings could know neither by experience nor by reason but solely by virtue of the divine revelation perpetuated in the Scripture (Melanchthon 1854b: 253-255). Therefore, only the Gospel was intrinsically empowered to make those, who were exposed to its message, accept it, by bringing them to faith. Thus, certainty in the arts except for theology was natural as wrought either by rational arguments or by empirical evidence, while in theology certainty was supernatural as created by the Spirit operating by God's Word.

Melanchthon remarked that genuine faith could not be regarded as a personal opinion resting on empirical or logical assumptions because faith as a sensible or rational inference would be vulnerable to doubt leading either to impiety or to despair (Melanchthon 1854b: 253-255; 333-340; 347349; 603-607; Melanchthon 1855: 51-62). Rather, genuine faith was, for Melanchthon, a firm and steady knowledge of the divine truth and a constant commitment to God's Word as to the revelation of God's benevolence 
towards humankind. Therefore, faith was said to rule out any doubt or uncertainty.

Consequently, Melanchthon rejected epistemological scepticism as exemplified by ancient Pyrrhonism which advocated doubting every statement or refraining from making any assertions (Melanchthon 1855: 51-62). Thus, such a sceptical approach must disregard a tradition which, for Melanchthon, was the knowledge accumulated by the past generations. In Melanchthon's view, the ancient legacy both in the humanities and in theology should be treasured, yet evaluated critically from the perspective of the sources peculiar to every academic discipline. In the case of theology $\mathrm{Me}-$ lanchthon accorded the status of the sole source of the credible saving knowledge of God to the Bible, admitting that the biblical teaching was subsequently mirrored in the ecumenical creeds.

Melanchthon argued that a sceptical stance could never be taken on the religion because it would nullify the divine assurance, that sinners were declared righteous in front of God for Christ's sake. In his opinion, the Holy Spirit created and sustained such an assurance in human heart through the means of grace and this assurance was the very essence of the Christian religion. In the case of the humanities exclusive of theology Melanchthon permitted of a doubt or of a suspension of assertions if there were no rational or empirical premisses to draw any inference or to make any assertions.

\section{Conclusion}

Melanchthon's Loci became the standard compendium by means of which generations of Protestant divines were instructed and edified. Luther did not object to this fact but rather appreciated the potential of Loci, realising that without Melanchthon's theological and educational insights the Wittenberg Reformation could not be fortified, might not expand beyond German-speaking territories and probably would not continue beyond Luther's own life (Luther 1908: 601; Luther 1909: 68-69; Luther 1931: 382386; Luther 1919: 204-205).

To a considerable degree, Melanchthon enunciated what is now commonly known as a doctrinal legacy of the 16th-century Wittenberg Reformation and unlike Luther, he was eulogised by Calvin as well. Between 1518 and 1519 Melanchthon (Melanchthon 1854b: 11-50; 49-60) formulated the Reformation concepts of free will, of the distinction between the Law and the Gospel, of the forensic nature of justification (Green 1980), of the Christian freedom and of the means of grace which subsequently solidified into his Loci of 1521. By 1518 Luther was not preoccupied with those topics and did not offer any systematic exposition of them. In the case of the concept of human free will in the spiritual sphere Luther's De servo arbitrio of 
1525 could be viewed as an explication of Melanchthon's disquisition on that topic from his Loci of 1521. Actually, Luther himself did not deny that he drew upon Philip's masterpiece (Luther 1908: 601).

From a historical perspective, the reception of Melanchthon's writings, for instance in Scandinavia, overshadowed that of Luther's tracts. Given that Luther himself avowed his own inaptitude to create any systematic exposition of theological tenets peculiar to the Wittenberg Reformation (Luther 1914: 657-658; Luther 1928: 179), Melanchthon's Loci were the instrument indispensable for educating the next generation of Protestant divines and for disseminating the ideas of the Reformation worldwide.

Although a theological programme presented in Melanchthon's Loci could not withstand the test of the Enlightenment humanities inclusive of the Enlightenment theology, his interpretation and systematisation of the doctrinal tenets, which he identified in the Scripture, served the purpose of

the 16th-century Reformation. Ultimately, religious symbols and concepts like all symbols and concepts are devised in a specific community at a specific time and in a specific place. Thus, Melanchthon's monumental work proved to be essential to the origin and formation of Reformation theology of the 16th century as an academic discipline and it paved the way for the further evolution of Protestant theology which demonstrated its remarkable ability to adapt to new and indeed every-changing circumstances.

\section{Bibliography}

Abraham ibn Daud (1852) Das Buch Emunah Ramah oder Der erhabene Glaube, edited and translated by Simson Weil. Frankfurt am Main: [s. n.].

Aelius Theon (1834) Progymnasmata, edited by Christoph Eberhard Finckh. Stuttgart: Loeflund.

Agricola R (1550) De formando studio: Epistola ad Jacobum Barbirianum. Paris: Calvarin.

Agricola R (1554) De inventione dialectica, edited by Johann Matthias Phrissemius. Paris: Porte.

Albo J (1844) Buch Ikkarim: Grund- und Glaubenslehren der Mosaischen Religion, trans. Wolf Schlessinger and Ludwig Schlesinger. Frankfurt am Main: [s. n.].

Ambrosius Mediolanensis (1880) De fide ad Gratianum Augustum libri quinque. In: PL, volume 16.

Andreä J, ed. (1584) Acta et scripta theologorum Wirtembergensium et Patriarchae Constantinopolitani D. Hieremiae quae utrique ab anno MDLXXVI usque ad annum MDLXXXI de Augustana Confessione inter se miserunt. Wittenberg: Crato. 
Aphthonius (1839) Progymnasmata Graece, edited by Julius Petzholdt. Leipzig: Boehme.

Augustinus Hipponensis (1843) De doctrina Christiana. In: PL, volume 34.

Augustinus Hipponensis (1845a) De fide ad Petrum sive de regula verae fidei. In: PL, volume 40.

Augustinus Hipponensis (1845b) Enchiridion ad Laurentium sive de fide, spe et charitate liber unus. In: PL, volume 40.

Baumgarten SJ (1754) Nachrichten von merkwürdigen Büchern, volume 31. Halle an der Saale: Gebauer.

Beyer M, ed. (1997-2012) Melanchthon Deutsch, volume 1-4. Leipzig: Evangelische Verlagsanstalt.

Bindseil HE (1868) Bibliotheca Melanthoniana. Halle an der Saale: Hendel.

Bizer E (1964) Theologie der Verheissung: Studien zur theologischen Entwicklung des jungen Melanchthon 1519-1524. Neukirchen-Vluyn: Neukirchener.

Boethius (1549a) De differentiis topicis. In: Dialectica, edited by Martianus Rota. Venice: Gryphius.

Boethius (1549b) In Topica Ciceronis. In: Dialectica, edited by Martianus Rota. Venice: Gryphius.

Breen Q (1947) The Terms 'Loci communes' and 'Loci' in Melanchthon. Church History 16(*): n.p.

Brüls A (1975) Die Entwicklung der Gotteslehre beim jungen Melanchthon 15181535. Bielefeld: Luther-Verlag.

Calvin J (1867) Opera quae supersunt omnia (Corpus Reformatorum), volume 6 (34), edited by Wilhelm Baum, Edouard Cunitz, and Eduard Reuss. Braunschweig: Schwetschke.

Calvin J (1870) Opera quae supersunt omnia (Corpus Reformatorum), volume 9 (37), edited by Wilhelm Baum, Edouard Cunitz, and Eduard Reuss. Braunschweig: Schwetschke.

Calvin J (1875) Opera quae supersunt omnia (Corpus Reformatorum), volume 14 (42), edited by Wilhelm Baum, Edouard Cunitz, and Eduard Reuss. Braunschweig: Schwetschke.

Calvin J (1877) Opera quae supersunt omnia (Corpus Reformatorum), volume 17 (45), edited by Wilhelm Baum, Edouard Cunitz, and Eduard Reuss. Braunschweig: Schwetschke.

Calvin J (1882) Opera quae supersunt omnia (Corpus Reformatorum), volume 51 (23), edited by Wilhelm Baum, Edouard Cunitz, and Eduard Reuss. Braunschweig: Schwetschke.

Cicero (1820a) Opera ex editionibus Oliveti et Ernesti, volume 1. London: Rodwell.

Cicero (1820b) Opera ex editionibus Oliveti et Ernesti, volume 2. London: Rodwell. 
Cicero (1820c) Opera ex editionibus Oliveti et Ernesti, volume 3. London: Rodwell.

Claus H, ed. (2014) Melanchthon-Bibliographie 1510-1560, volume 1-4. Gütersloh: Gütersloher Verlagshaus.

Crell P (1560) Pio lectori S. D. In: Orationes aliquot recitatae in Academia Witebergensi eo tempore quo praelectiones publicas reverendi et clarissimi viri Philippi Melanthonis obitu huius interruptas aliqui ex professoribus de consilio Academiae continuare ceperunt. Wittenberg: Creutzer.

Cyrillus Hierosolymitanus (1857a) Catecheses. In: PG, volume 33.

Cyrillus Hierosolymitanus (1857b) Catecheses mystagogicae quinque. In: PG, volume 33.

Dingel I, ed. (2011) Philipp Melanchthon: Lehrer Deutschlands, Reformator Europas. Leipzig: Evangelische Verlagsanstalt.

Dingel I, ed. (2012) Philip Melanchthon: Theologian in Classroom, Confession, and Controversy. Göttingen: Vandenhoeck \& Ruprecht.

Engelland H (1930) Die Frage der Gotteserkenntnis bei Melanchthon. München: Kaiser.

Epiphanius (1863) Panarium sive Arcula adversus octoginta haereses. In: PG, volume 41.

Erasmus Rotterdamus (1519) Ratio seu compendium verae theologiae. Basel: Froben.

Erasmus Rotterdamus (1540) De duplici copia verborum ac rerum commentarii duo. In: Omnia opera, volume 1. Basel: Froben.

Eusebius Caesariensis (1857a) Demonstratio evangelica. In: PG, volume 22.

Eusebius Caesariensis (1857b) Praeparatio evangelica. In: PG, volume 21.

Fraenkel P (1961) Testimonia Patrum: The Function of the Patristic Argument in the Theology of Philip Melanchthon. Geneva: Droz.

Frank G, ed. (2001-2002) Melanchthon und Europa, volume 1-2. Stuttgart: Thorbecke.

Frank G, ed. (2005) Melanchthon und der Calvinismus. Stuttgart and Bad Cannstatt: Frommann-Holzboog.

Fulgentius (1847) De fide seu de regula verae fidei ad Petrum liber unus. In: PL, volume 65.

Galle F (1840) Versuch einer Charakteristik Melanchthons als Theologen und einer Entwickelung seines Lehrbegriffs. Halle an der Saale: Lippert.

Geyer HG (1965) Von der Geburt des wahren Menschen: Probleme aus den Anfängen der Theologie Melanchthons. Neukirchen-Vluyn: Neukirchener.

Graybill GB (2010) Evangelical Free Will: Philipp Melanchthon's Doctrinal Journey on the Origins of Faith. Oxford: Oxford University Press.

Green LC (1980) How Melanchthon Helped Luther Discover the Gospel: The Doctrine of Justification in the Reformation. Fallbrook: Verdict Publications.

Greschat M (1965) Melanchthon neben Luther: Studien zur Gestalt der Rechtfertigungslehre zwischen 1528 und 1537. Witten: Luther-Verlag. 
Hall HA (2014) Philip Melanchthon and the Cappadocians: A Reception of Greek Patristic Sources in the Sixteenth Century. Göttingen: Vandenhoeck \& Ruprecht.

Hardt H (1717) Phil. Melanchthonis Hypotyposes theologicae An. 1521 opus rarissimum. In: Historia literaria reformationis in honorem iubilaei anno MDCCVII. Frankfurt am Main and Leipzig: Renger.

Heinrich P (2003) Die Frage der menschlichen Willensfreiheit in der Theologie Melanchthons: Eine kurze Darstellung und Beurteilung ihrer Aufnahme und Entwicklung unter besonderer Berücksichtigung der Loci communes. Nordhausen: Bautz.

Hermogenes (1812) Progymnasmata Graece, edited by Arnold H. L. Heeren and Georg Veesenmeyer. Nuremberg: Lechner.

Herrlinger A (1879) Die Theologie Melanchthons in ihrer geschichtlichen Entwicklung und im Zusammenhang mit der Lehrgeschichte und Kulturbewegung der Reformation. Gotha: Perthes.

Hessus HE, ed. (1544) Psalterium Davidis carmine. Strasbourg: Crato.

Hugo de Sancto Victore (1880) Summa sententiarum. In: PL, volume 176.

Joannes Damascenus (1864) Expositio fidei orthodoxae. In: PG, volume 94.

Judah Halevi (1905) Kitab al Khazari, trans. Hartwig Hirschfeld. London: Routledge.

Keckermann B (1606) Rhetoricae ecclesiasticae sive Artis formandi et habendi conciones sacras libri duo. Hanau: Antonius.

Kolb R (1997) The Ordering of the Loci Communes Theologici: The Structuring of the Melanchthonian Dogmatic Tradition. Concordia Journal 23.

Kolb R (2003) Melanchthonian Method as a Guide to Reading Confessions of Faith: The Index of the Book of Concord and Late Reformation Learning. Church History 72(*): n.p.

Kuropka N (2002) Philipp Melanchthon, Wissenschaft und Gesellschaft. Ein Gelehrter im Dienst der Kirche 1526-1532. Tübingen: Mohr.

Lactantius (1844) Divinarum Institutionum libri septem. In: PL, volume 6.

Leiner M (1997) Die Anfänge der protestantischen Hermeneutik bei Philipp Melanchthon: Ein Kapitel zum Verhältnis von Rhetorik und Hermeneutik. Zeitschrift für Theologie und Kirche 94(*): n.p.

Luther M (1908) De servo arbitrio. In: WA, volume 18.

Luther M (1909) Vorrede zu Melanchthons verdeutschter Auslegung des Kolosserbriefs. In: WA, volume 30/II.

Luther M (1914) Vorrede zum 1. Band der Wittenberger Ausgabe der Deutschen Schriften. In: WA, volume 50.

Luther M (1919) Kaspar Heidenreichs Nachschriften (Winter von 1542 auf 1543). In: WA TR, volume 5.

Luther M (1928) Vorrede zum ersten Band der Gesamtausgabe der Lateinischen Schriften. In: WA, volume 54. 
Luther M (1931) An Melanchthon (Wartburg, 9. September 1521). In: WA BR, volume 2 .

Maag K, ed. (1999) Melanchthon in Europe. His Work and Influence beyond Wittenberg. Grand Rapids: Baker Books.

Mack P (1993) Renaissance Argument: Valla and Agricola in the Traditions of Rhetoric and Dialectic. Leiden: Brill.

Maimonides (1923-1924) Führer der Unschlüssigen, volume 1-3, trans. Adolf Weiss. Leipzig: Meiner.

Matz W (2001) Der befreite Mensch: Die Willenslehre in der Theologie Philipp Melanchthons. Göttingen: Vandenhoeck \& Ruprecht.

Maurer W (1964) Melanchthon-Studien. Gütersloh: Mohn.

Maxcey CE (1980) Bona Opera: A Study in the Development of the Doctrine in Philip Melanchthon. Nieuwkoop: De Graaf.

Maximus Abbas (1865) Capita theologiae et oeconomiae. In: PG, volume 90.

Mayes BTG (2011) Introduction to the Second Edition. In: Philipp Melanchthon, The Chief Theological Topics: Loci praecipui theologici 1559, trans. Jacob Aall Ottesen Preus. St. Louis: Concordia Publishing House.

Meijering EP (1983) Melanchthon and Patristic Thought: The Doctrines of Christ and Grace, the Trinity and the Creation. Leiden: Brill.

Melanchthon P (1522) Die Hauptartikel und vornehmsten Punkten der ganzen heiligen Schrift, trans. Georg Spalatin. Strasbourg: [s. n.].

Melanchthon P (1523a) Anweisung in die wahrhaftige heilige Schrift Gottes, trans. Georg Spalatin. Augsburg: Grimm.

Melanchthon P (1523b) Institutiones rhetoricae. Strasbourg: Hervag.

Melanchthon P (1525) De locis communibus. In: De rhetorica libri tres. Cologne: Cervicornus.

Melanchthon P (1536) Loci communes das ist die vornehmsten Artikel Christlicher Lehre, trans. Justus Jonas. Wittenberg: Rhau.

Melanchthon P (1544a) Die Hauptartikel Christlicher Lehre zusammen gezogen, trans. Justus Jonas. Wittenberg: Rhau.

Melanchthon P (1544b) Loci communes theologici. Frankfurt am Main: Braubach.

Melanchthon P (1545) De dialectica libri quatuor. Strasbourg: Mylius.

Melanchthon P (1546a) La somme de theologie ou lieux communs, edited by Jean Calvin. Geneva: Girard.

Melanchthon P (1546b) Loci communes theologici. Leipzig: Papa.

Melanchthon P (1546c) Oratio in funere reverendi viri D. Martini Lutheri. Wittenberg: [s. n.].

Melanchthon P (1551) La somme de theologie ou lieux communs, edited by Jean Calvin. Geneva: Crespin. 
Melanchthon P (1555) Commentaire sur le livre des révélations du prophète Daniel, edited by Jean Calvin. Geneva: Crespin.

Melanchthon P (1560a) Corpus doctrinae christianae das ist ganze Summa der rechten wahren christlichen Lehre des heiligen Evangeliums nach Inhalt göttlicher prophetischen und apostolischen Schriften. Leipzig: Voegelin.

Melanchthon P (1560b) Corpus doctrinae christianae quae est summa orthodoxi et catholici dogmatis complectens doctrinam puram et veram Evangelii Jesu Christi secundum divina prophetarum et apostolorum scripta. Leipzig: Voegelin.

Melanchthon P (1567) Initia doctrinae physicae. Wittenberg: Crato.

Melanchthon P (1584) Erotemata dialectices. Wittenberg: Schleich.

Melanchthon P (1592) Elementorum rethorices libri duo. Wittenberg: Ruehel.

Melanchthon P (1824) Responsiones ad impios articulos Bavaricae inquisitionis, edited by Ernst Sartorius. Marburg: Krieger.

Melanchthon P (1835) Opera quae supersunt omnia (Corpus Reformatorum), volume 2, edited by Karl Gottlieb Bretschneider. Halle an der Saale: Schwetschke.

Melanchthon P (1837) Opera quae supersunt omnia (Corpus Reformatorum), volume 4, edited by Bretschneider. Halle an der Saale: Schwetschke.

Melanchthon P (1839) Opera quae supersunt omnia (Corpus Reformatorum), volume 6, edited by Karl Gottlieb Bretschneider. Halle an der Saale: Schwetschke.

Melanchthon P (1840) Opera quae supersunt omnia (Corpus Reformatorum), volume 7, edited by Karl Gottlieb Bretschneider. Halle an der Saale: Schwetschke.

Melanchthon P (1841) Opera quae supersunt omnia (Corpus Reformatorum), volume 8, edited by Karl Gottlieb Bretschneider. Halle an der Saale: Schwetschke.

Melanchthon P (1842) Opera quae supersunt omnia (Corpus Reformatorum), volume 9, edited by Karl Gottlieb Bretschneider. Halle an der Saale: Schwetschke.

Melanchthon P (1848) Opera quae supersunt omnia (Corpus Reformatorum), volume 15, edited by Karl Gottlieb Bretschneider. Halle an der Saale: Schwetschke.

Melanchthon P (1850) Opera quae supersunt omnia (Corpus Reformatorum), volume 16, edited by Karl Gottlieb Bretschneider and Heinrich Ernst Bindseil. Halle an der Saale: Schwetschke.

Melanchthon P (1854a) Opera quae supersunt omnia (Corpus Reformatorum), volume 20, edited by Karl Gottlieb Bretschneider and Heinrich Ernst Bindseil. Braunschweig: Schwetschke.

Melanchthon P (1854b) Opera quae supersunt omnia (Corpus Reformatorum), volume 21, edited by Karl Gottlieb Bretschneider and Heinrich Ernst Bindseil. Braunschweig: Schwetschke. 
Melanchthon P (1855) Opera quae supersunt omnia (Corpus Reformatorum), volume 22, edited by Karl Gottlieb Bretschneider and Heinrich Ernst Bindseil. Braunschweig: Schwetschke.

Melanchthon P (2010) Heubtartikel christlicher Lere: Melanchthons deutsche Fassung seiner Loci theologici nach dem Autograph und dem Originaldruck von 1553, edited by Ralf Jenett and Johannes Schilling. Leipzig: Evangelische Verlagsanstalt.

Neuser WH (1968) Die Abendmahlslehre Melanchthons in ihrer geschichtlichen Entwicklung 1519-1530. Neukirchen-Vluyn: Neukirchener.

Nysaeus J (1560) Tabulae locorum communium theologicorum Philippi Melanchthonis confectae. Basel: Oporinus.

Origenes (1857) Peri archōn. In: PG, volume 11.

Pauli F (1996) Philippus: Ein Lehrer für Deutschland. Spuren und Wirkungen Philipp Melanchthons. Berlin: Wichern-Verlag.

Petrus Abaelardus (1855a) Sic et non. In: PL, volume 178.

Petrus Abaelardus (1855b) Theologia Christiana. In: PL, volume 178.

Petrus Lombardus (1855) Sententiarum libri quatuor. In: PL, volume 192.

Pitkin B (2004) The Protestant Zeno: Calvin and the Development of Melanchthon's Anthropology. The Journal of Religion 84(*): 347-378.

Plitt GL, Kolde T (1890) Melanchthons theologische Entwicklung bis zur Herausgabe der Loci communes. In: Die Loci Communes Philipp Melanchthons in ihrer Urgestalt, edited by Gustav Leopold Plitt and Theodor Kolde. Erlangen and Leipzig: Deichert.

Priscianus (1545) De praeexercita mentis rhethoricae ex Hermogene liber. In: Libri omnes. Basel: Bryling.

Quintilianus (1725) De oratoria institutione libri XII, edited by Claude Capperonnier. Paris: Coustelier.

Rödiger M (1829) Insunt quaedam de Philippi Melanthonis Locis communibus theologicis propediem in Corpore Reformatorum edendis. Halle an der Saale: Gebauer.

Rufinus (1878) Commentarius in Symbolum Apostolorum. In: PL, volume 21.

Saadia G (1845) Glaubenslehre und Philosophie, edited and translated by Julius Fürst. Leipzig: Wigand.

Schaff P (1958) Calvin and Melanchthon. In: History of the Christian Church, volume 8. Grand Rapids: Eerdmans.

Schäfer R (1961) Christologie und Sittlichkeit in Melanchthons frühen Loci. Tübingen: Mohr.

Scheible H, ed. (1997) Melanchthon in seinen Schülern. Wiesbaden: Harrassowitz.

Scheible H (2010) Aufsätze zu Melanchthon. Tübingen: Mohr. 
Schirmer A (1967) Das Paulusverständnis Melanchthons 1518-1522. Wiesbaden: Steiner.

Schofield J (2006) Philip Melanchthon and the English Reformation. Aldershot: Ashgate.

Schwarzenau P (1956) Der Wandel im theologischen Ansatz bei Melanchthon von 1525-1535. Gütersloh: Bertelsmann.

Sell K (1897) Philipp Melanchthon und die Deutsche Reformation bis 1531. Halle an der Saale: Verein für Reformationsgeschichte.

Sotheby SL (1839) Observations upon the Handwriting of Philip Melanchthon. London: Davy.

Stolt B, ed. (1998) Philipp Melanchthon und seine Rezeption in Skandinavien. Stockholm: Almqvist \& Wiksell.

Strobel GT (1776) Versuch einer Literärgeschichte von Philipp Melanchthons Locis Theologicis als dem ersten Evangelischen Lehrbuch. Altdorf and Nürnberg: Schüpfel.

Strobel GT, ed. (1782) Bibliotheca Melanchthoniana. Nuremberg: [s. n.].

Stupperich R (1973) Melanchthons Deutsche Bearbeitung seiner Loci nach der Olmützer Handschrift. In: Mededelingen: Koninklijke Nederlandse Akademie van Wetenschappen, Afdeeling Letterkunde, Nieuwe Reeks, volume 36/7. Amsterdam and London: North-Holland Publishing Company.

Theodotus Ancyranus (1864) Expositio Symboli Nicaeni. In: PG, volume 77.

Vincentius Lirinensis (1865) Duo Commonitoria. In: PL, volume 50.

Weber F (1880) System der altsynagogalen palästinischen Theologie aus Targum, Midrasch und Talmud. Leipzig: Dörfling and Franke.

Wengert TJ (1997) Law and Gospel: Philip Melanchthon's Debate with John Agricola of Eisleben over Poenitentia. Carlisle: Paternoster.

Wengert TJ (1998) Human Freedom, Christian Righteousness: Philip Melanchthon's Exegetical Dispute with Erasmus of Rotterdam. New York, NY: Oxford University Press.

Wengert TJ (2009) The Rhetorical Paul: Philip Melanchthon's Interpretation of the Pauline Epistles. In: A Companion to Paul in the Reformation, edited by R. Ward Holder. Leiden: Brill.

Wiedenhofer S (1976) Formalstrukturen humanistischer und reformatorischer Theologie bei Philipp Melanchthon, volumes 1-2. Bern: Lang.

Zachman RC (2006) John Calvin as Teacher, Pastor, and Theologian. The Shape of His Writings and Thought. Grand Rapids, MI: Baker Academic. 